\title{
Endometrial cancer after the Manchester procedure: a nationwide cohort study
}

\author{
Karen Husby $^{1}$, Kim Gradel $^{2}$, and Niels Klarskov ${ }^{1}$ \\ ${ }^{1}$ Herlev Hospital \\ ${ }^{2}$ Odense University Hospital
}

December 20, 2021

\begin{abstract}
Objectives To investigate whether the Manchester procedure affects the risk and prognosis of endometrial cancer. Design Nationwide historical cohort. Setting The nationwide Danish registers including all residents with lifelong follow-up. Population All Danish women born 1947-2000, living in Denmark at one point during 1977-2018 undergoing the Manchester procedure (N $=23,935$ ) or anterior colporrhaphy (reference group $\mathrm{N}=51,008$ ) during 1977-2018. Methods We conducted a nationwide cohort with full follow-up. Chi-Square test for trend to compare the diagnostic stage for the two groups of women. Cox Regression to analyse the risk of endometrial cancer and mortality. The models were adjusted for age, calendar year, income level, and parity. Main outcome measures Number of women diagnosed with endometrial cancer, the stage of endometrial cancer at the time of diagnosis and the cancer specific and overall mortality. Results During the follow up (median 13 years), 271 (1.13\%) women were diagnosed with endometrial cancer after the Manchester procedure and $520(1.05 \%)$ after anterior colporrhaphy. The adjusted hazard ratio (HR) for endometrial cancer was 1.00 (95\% confidence interval (CI) 0.86 to 1.16). No difference in stage of cancer was found $(\mathrm{p}=0.18)$, nor when stratifying for calendar year. The HR for cancer specific mortality and overall mortality after the Manchester procedure was 0.86 (95\% CI 0.65 to 1.15) and 0.93 (95\% CI 0.77 to 1.12) respectively. Conclusions The Manchester procedure does not affect the risk or prognosis of endometrial cancer. Keywords Epidemiology, endometrial cancer, Manchester procedure, uterine prolapse, pelvic organ prolapse, vaginal hysterectomy
\end{abstract}

\section{Hosted file}

BJOG Endometrial cancer after the Manchester procedure 20211216.docx available at https: //authorea.com/users/451982/articles/550164-endometrial-cancer-after-the-manchesterprocedure-a-nationwide-cohort-study

Hosted file

tables.docx available at https://authorea.com/users/451982/articles/550164-endometrialcancer-after-the-manchester-procedure-a-nationwide-cohort-study 


\begin{tabular}{|c|c|}
\hline \multicolumn{2}{|c|}{$\begin{array}{l}\text { Manchester procedures and anterior colporrhaphies performed during 1977-2018 on women born } \\
\qquad 1974-2018 \text {, living in Denmark 1977-2018 } \mathrm{N}=96,098\end{array}$} \\
\hline \multicolumn{2}{|c|}{ Women emigrated for more than two years prior to operation $N=1,296$} \\
\hline \multicolumn{2}{|c|}{ Women hysterectomized prior to operation $\mathrm{N}=19,534$} \\
\hline \multicolumn{2}{|c|}{ Women diagnosed with gynecological cancer or censured prior to operation $N=270$} \\
\hline \multicolumn{2}{|c|}{ Women diagnosed with gynecological cancer within 90 days from operation $\mathrm{N}=35$} \\
\hline \multicolumn{2}{|c|}{ Women younger than 20 at the time of operation $\mathrm{N}=20$} \\
\hline \multicolumn{2}{|c|}{ Study population $\mathrm{N}=74,943$} \\
\hline $\begin{array}{l}\text { Manchester procedure } \\
\qquad \mathrm{N}=23,935\end{array}$ & $\begin{array}{l}\text { Anterior colporrhaphy } \\
\qquad \mathrm{N}=51,008\end{array}$ \\
\hline \multicolumn{2}{|l|}{ 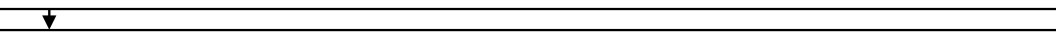 } \\
\hline \multicolumn{2}{|c|}{ Subpopulation of women diagnosed with endometrial cancer $\mathbf{N}=791$} \\
\hline $\begin{array}{l}\text { Manchester procedure } \\
\qquad N=271\end{array}$ & $\begin{array}{l}\text { Anterior colporrhaphy } \\
\qquad \mathrm{N}=520\end{array}$ \\
\hline
\end{tabular}



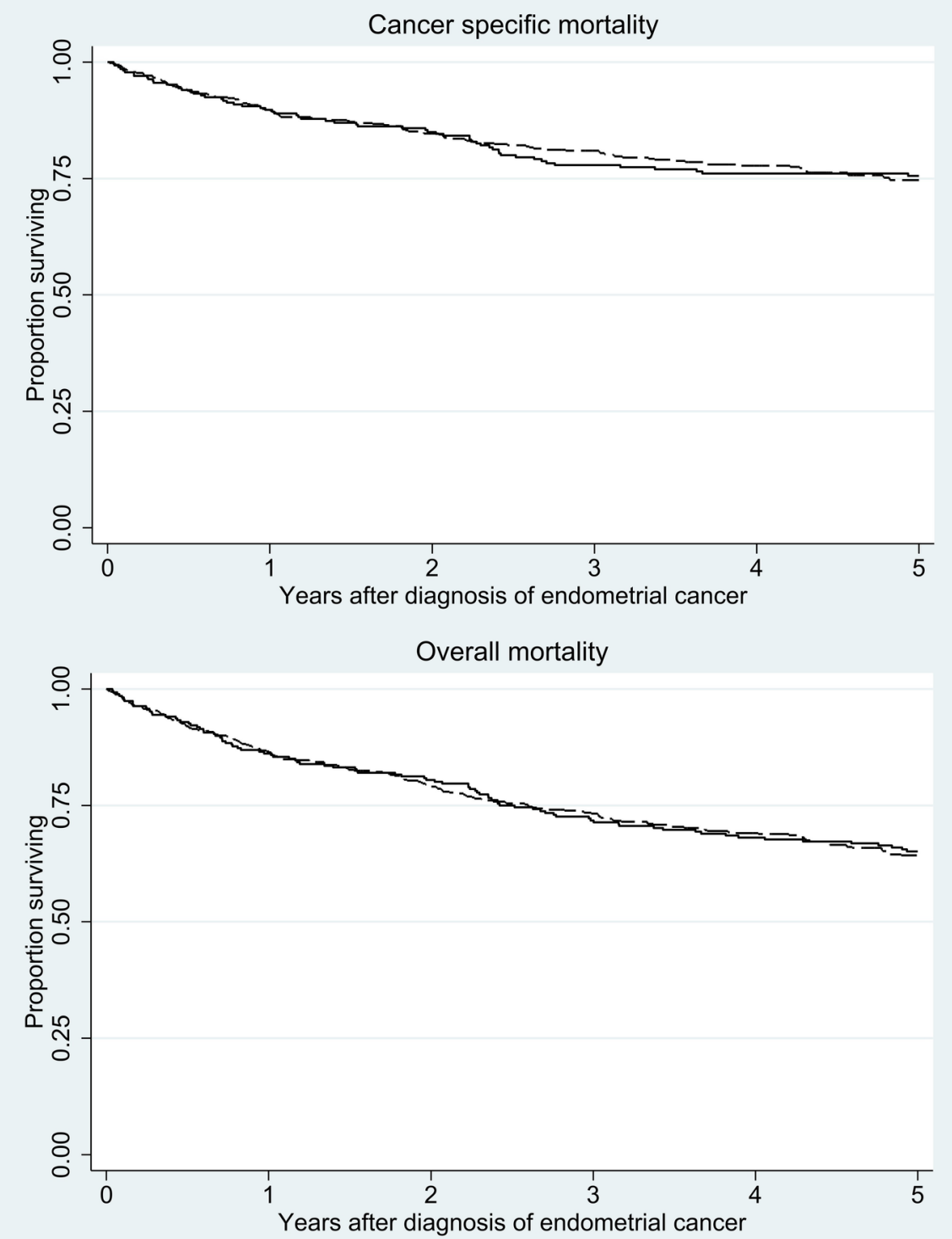

The Manchester procedure $\quad--$ Anterior colporrhaphy 